Journal of Finance and Banking Review

Journal homepage: www.gatrenterprise.com/GATRJournals/index.html

J. Fin. Bank. Review 1 (1) $40-46$ (2016)

\title{
Corporate Social Responsibility as a Means of Performance Enhancement: The Case of a Cement Plant in Setif (Algeria)
}

\author{
Hamoudi Hadj Sahraoui* \\ Senior Lecturer at the Faculty of Economics, Setif University, Algeria.
}

\begin{abstract}
Objective - The main concern of this article is to see if the implementation of the Corporate Social Responsibility (CSR) can lead to enterprise performance.

Methodology/Technique -A case study, this paper aims to compare the economic, social and environmental performance of one of the biggest cement producing enterprises in Algeria, before and after the implementation of the CSR strategy.

Findings - Results indicate that the SCAEK Company managers who had embarked on the strategy of reducing all kinds of pollutions emitted did not stop when they had achieved their objective. Instead, they continued with their movement by setting up new measures to reduce the quantities of some inputs used and to improve the working conditions of all the employees.

Novelty - This paper highlights the fact that the right implementation of the CSR, even if it does require some additional costs, can result in a "win-win" situation.
\end{abstract}

Type of Paper: Empirical

Keywords: CSR, Enterprise Performance, Cement Production, Algeria.

JEL Classification: M14, M21.

\section{Introduction}

The concept of Corporate Social Responsibility (CSR) is widely used these days and it refers, to the responsibility of the enterprise in concentrating not only on its activities of achieving profit goals and complying with rules, but also to go beyond that and meet the needs and expectations of the society. This appears to suggest that an enterprise has a social responsibility towards the community it serves even though adopting the CSR strategy may incur some extra costs which could hurt shareholders' interests. Hence, the aim of this paper is to investigate if the adoption of the CSR is incompatible with profit achieving. The main question to ask is, "What can be gained by the enterprise that complies with the CSR requirement?" To answer this core question, the current study and its process of work would be divided into three parts. Part one reviews some of the definitions provided for the CSR. Part two investigates the relationship that links the CSR to the enterprise's economic performance. Finally, part three attempts to answer the above core question in light of

\footnotetext{
${ }^{*}$ Paper Info: Received: September 20, 2016

Accepted: December 17, 2016

* Corresponding author:

E-mail: hamoudihs@yahoo.fr

Affiliation: Faculty of Economics, Setif University, Algeria.
} 
the case study of an Algerian cement plant. The methodology adopted for the last part consists of comparing the economic performance of the cement plant before and after it adopted the implementation of the CSR.

\section{Literature Review}

It is worth noting that Bowen, in 1953, was the first to use the term, socially responsible, in a book he edited (Fifka, 2009). Due to the complexity of the concept, the definition of the Corporate Social Responsibility, henceforth, CSR, has seen a big evolution in the last sixty years. As a result of the myriad definitions imposed, this paper will thus focus only on the significant efforts that have been made by researchers in the last few years. This may help in refining the CSR concept in a more precise manner.

Elhauge defined CSR as the financial sacrifices that have benefits for the company (see Benabou \& Tirole 2010). Fifka (2009), however stated that CSR is the legal and economic commitment and the voluntary responsibility of an enterprise to participate in the development of the society that surrounds it. Tirole and Benabou added the legal aspect of CSR by injecting the principle of voluntarism. Based on this, it can be said that social responsibility must include a large set of behaviors such as social ethics, environment friendliness and respect for society, all of which can affect employees.

From another perspective, the European Commission defined CSR as "A concept through which companies can integrate social, environmental and economic commitments in their operation and interaction with stakeholders on a voluntary basis" (Green Paper, 2010). This means that companies need to demonstrate the loyalty towards their legal commitment to investing in human capital, the environment and the relationship with stakeholders.

From the different definitions noted above, it can be seen that in order to be competitive, the economic enterprise is asked to not only fulfill some tasks that go beyond the scope of its conventional activities but to also support the additional costs incurred which may hurt shareholders' interests. This controversial statement was debated by many academicians in the last few years. As a result, many empirical studies were carried out to study the relation that may link CSR to financial performance. The findings of prior studies clearly indicated that scholars are still divided between for and against adopting the CSR as a business strategy. Nonetheless, this paper attempts to disclose some of these works.

Some studies of CSR concentrated mainly on the impact of taking measures to preserve the environment. Among these, one of the most quoted is the one conducted by Porter and Van der Linde (1995). Their findings noted that "Innovating to meet (environmental) regulations can bring offsets: using inputs better, creating better products, or improving product yield." (p.125). The researchers noted that there is a positive relation between fighting pollution and financial performance. In the same order, Stefan and Paul (2008), through an empirical study, reported that CSR was meant to "show that the expenses incurred to reduce pollution can be partly or completely offset by gains made elsewhere" (p.57). The main findings of the study indicated that some enterprises, with certain characteristics, can benefit from improving the environmental performance through opportunities of reducing costs and opportunities of increasing revenues.

Other studies looking at CSR were based on the stakeholder theory which was developed by Freeman (1984). Here, the study explored how adopting a CSR strategy can positively affect the interests of all parties that have any relation with the enterprise, for example, shareholders, employees, suppliers, customers and the local community. One of the most comprehensive studies done on CSR was the one conducted by Srivastava et al., (2012). Their objective was to examine how CSR was implemented in one of the biggest companies in India (TATA group). Their findings noted that "Social involvement of business would enhance a harmonious and healthy relationship between the society and business, seeking mutual benefit for all parties. Social involvement may create a better public image and goodwill for the company which further becomes instrumental in attracting customers, efficient personnel and investors." (p.26). Another study worth mentioning is the one performed by Uadiale and Fagbemi (2012). Their objective was to empirically investigate the impact of CSR activities on the financial performance of some companies in Nigeria. They used the econometric relation of return on equity (ROE) and return on assets (ROA) as dependent variables in each 
model and CSR was measured by 3 variables: community performance, environment management system and employee relations. Their results indicated that CSR has a positive and significant impact on financial performance. In another study, Islam et al., (2012) examined the relation that links CSR to financial performance in the banking sector of Bangladesh. They used a questionnaire survey sent to 20 domestic private banks with returns of only 17. Their findings indicated that the five banks that were classified as CSR banks had performed financially much better than the other 12 banks.

In their study, Margolis and Walsh (2003) investigated 127 published studies which focused on the relation between CSR and financial performance from 1972 to 2002. Their results are summarized in Table 1.

Table 1. Empirical studies results

\begin{tabular}{|l|l|l|l|l|l|}
\hline $\begin{array}{l}\text { The studies that } \\
\text { treated CSR as }\end{array}$ & Number & $\begin{array}{l}\text { Positive } \\
\text { relationship }\end{array}$ & $\begin{array}{l}\text { Negative } \\
\text { relationship }\end{array}$ & $\begin{array}{l}\text { Non } \\
\text { significant } \\
\text { relationship }\end{array}$ & $\begin{array}{l}\text { Mixed } \\
\text { relationship* }\end{array}$ \\
\hline an independent variable & 109 & $\begin{array}{l}54 \\
(49.55 \%)\end{array}$ & $\begin{array}{l}7 \\
(6.42 \%)\end{array}$ & $\begin{array}{l}28 \\
(25.68 \%)\end{array}$ & $\begin{array}{l}20 \\
(18.35 \%)\end{array}$ \\
\hline a dependent variable & 22 & $\begin{array}{l}16 \\
(72.72 \%)\end{array}$ & $\begin{array}{l}\text { Not } \\
\text { mentioned }\end{array}$ & - & - \\
\hline
\end{tabular}

Source: The author, from Margolis and Walsh (2003).

From the results noted in the table, it can be seen that the total number of studies totaled 131 instead of 127. This is due to the fact that 4 of the 127 studies treated CSR both as an independent variable and a dependent variable. A more recent literature review on the same subject (Raza et al., 2012), using content analysis, observed studies that were conducted from 1972 to 2012 and their findings are summarized in Table 2.

Table 2. The nature of the relationship between RSE and financial performance

\begin{tabular}{|l|l|l|l|l|l|}
\hline $\begin{array}{l}\text { Financial performance } \\
\text { measured by }\end{array}$ & Number & $\begin{array}{l}\text { Positive } \\
\text { relationship }\end{array}$ & $\begin{array}{l}\text { Negative } \\
\text { relationship }\end{array}$ & $\begin{array}{l}\text { Non- } \\
\text { significant } \\
\text { relationship }\end{array}$ & $\begin{array}{l}\text { Mixed } \\
\text { relationship* }\end{array}$ \\
\hline ROA, ROE, and ROS** & 45 & $\begin{array}{l}35 \\
(77.77 \%)\end{array}$ & $\begin{array}{l}0 \\
(0.00 \%)\end{array}$ & $\begin{array}{l}9 \\
(20.00 \%)\end{array}$ & $\begin{array}{l}1 \\
(2.23 \%)\end{array}$ \\
\hline $\begin{array}{l}\text { Market to book ratio or } \\
\text { Tobin's Q }\end{array}$ & 06 & $\begin{array}{l}6 \\
(100 \%)\end{array}$ & - & - & - \\
\hline Stock market returns & 25 & $\begin{array}{l}7 \\
(28.00 \%)\end{array}$ & $\begin{array}{l}8 \\
(32.00 \%)\end{array}$ & $\begin{array}{l}7 \\
(28.00 \%)\end{array}$ & $\begin{array}{l}3 \\
(12.00 \%)\end{array}$ \\
\hline
\end{tabular}

Source: The author, from Raza et al., (2012).

Here, it can be seen that $\left(^{*}\right)$ mixed relationship as noted in both tables had used the CSP as a multidimensional concept where different kinds of relationships were found for different dimensions. (Lerner and Fryxell, 1988). Further, as is shown in the table, (**) serves as the abbreviations for Return on assets, Return on equity and Return on sales respectively. From the results seen, it can be concluded that majority of the empirical studies had reported a positive relationship between the CSR and financial performance. This means that CSR can enhance the enterprise performance.

\section{Research Method}

The main aim of the current case study is to assess the impact of implementing the CSR as a strategy on the firm's economic performance. In this case study, a comparison is made of the economic, social and environmental performance of one of the biggest cement producing enterprises in Algeria, before and after the 
implementation of the CSR strategy. Data were gathered from the said enterprise/company report which was published in 2012 and which discussed its environmental approach.

In order to answer the core question of this study, as mentioned above, the following hypotheses were formulated:

$\mathbf{H}_{1}$ : implementing a CSR strategy has a positive effect on economic performance,

$\mathbf{H}_{2:}$ implementing a CSR strategy has a positive effect on social performance,

$\mathbf{H}_{3}$ : implementing a CSR strategy has a positive effect on environmental performance.

With a theoretical production capacity of one Million Tons per year, the SCAEK can be regarded as one of the most important cement producing enterprises. It plays a key role in supplying Algeria's building projects with cement. It is located in the East of Algeria, about $330 \mathrm{~km}$ from the capital of Algiers. It began operating in 1978 and it employs, at the time of being studied, a total of 451 employees. Despite its importance, the enterprise has always been criticized by the surrounding population for its emission of many undesirable atmosphere pollutants. In 2006, the enterprise decided to embark on a huge project which was meant to achieve three objectives:

- Reducing dust and greenhouse gas emissions,

- Reducing energy intensity of its products,

- Improving employees' working conditions.

In an attempt to assess the impact of this project, the current study first of all, perused the main lines of the investment program and then compared the outcome with the enterprise's economic, social and environment performances; before and after 2006.

The SCAEK decided in 2006 to embark on this project and its main aim was to embark on an investment project which consisted mainly of replacing the old electro filters with new ones called bag filters. In order to comply with environmental regulations and to avoid spoiling the neighborhood atmosphere, the enterprise has to embark on acquiring a new characteristic which is characterized by much more cleaning efficiency and less water and electricity consumption. The operation took place in 2006 with the following aim:

- Installation of new pre-ashing equipment,

- Renewal of the clinker air cooler,

- Implementation of an environmental management system,

- Installation of a computerized maintenance management system,

- Installation of an innovative electronic document management system.

The yearly expenditure which this ambitious project would amount is shown in Table 3 .

Table 3. SCAEK investment expenditure on its enterprise environmental approach

\begin{tabular}{|l|l|l|l|}
\hline Year & $\begin{array}{l}\text { Investment expenditure } \\
\left(\mathbf{1 0}^{\mathbf{3}} \text { Euro }\right)\end{array}$ & $\begin{array}{l}\text { Yearly sales } \\
\left(\mathbf{1 0}^{\mathbf{3}} \text { Euro }\right)\end{array}$ & $\begin{array}{l}\text { Annual investment as \% } \\
\text { of yearly sales }\end{array}$ \\
\hline 2006 & 10972,54 & 33410 & $33 \%$ \\
\hline 2007 & 10114,65 & 41230 & $25 \%$ \\
\hline 2008 & 7372,25 & 43640 & $17 \%$ \\
\hline 2009 & 2208,22 & 47760 & $5 \%$ \\
\hline 2010 & 70 & 70810 & $0,1 \%$ \\
\hline 2011 & 650 & 66780 & $1 \%$ \\
\hline Total & 31387,66 & 303630 & - \\
\hline
\end{tabular}

Source: The author from The SCAEK environmental approach report (2012) 
From the above table, it can be seen that there is a vast difference in terms of expenditure, yearly sales and $\%$. This attempt by the enterprise is deemed considerable as it embarks on tackling the problem of pollution.

As can be noted, it is undeniable that the investment project the enterprise had embarked on at the beginning was to protect the environment and when implemented, it was very successful. In fact, the volume of the plant emissions i.e., stack dust, nitrogen oxide and sulfur dioxide was reduced from $200 \mathrm{~g} / \mathrm{Nm} 3$ to $10 \mathrm{mg} / \mathrm{Nm} 3$. The enterprise went a step further, as a public enterprise, it also conducted a human resource strategy that could encourage its employees to do their best in achieving the company's objectives.

In addressing the research problem of this paper, the impact of the implementation of CSR by the said enterprise is assessed in order to see its impact on the economic performance and this is assessed through its environmental approach. To achieve this, output and input indicators were relied on and their evolution before and after adopting the EEA were investigated.

Results indicated that Production Volume and Value Added (VA) can be considered, as far as the industrial enterprise is concerned, as key performance indicators. While Production indicated the raw volume of goods produced each year, VA is considered as the difference between output and input. In fact, VA expresses the wealth created by the enterprise. Hence, these two indicators can be considered as well-suited for tracing the evolution of SCAEK's economic performance before and after the implementation of the EEA. From the accounting records acquired, it was noted that the production was expressed in tons and the VA during the period from 2000 to 2014.

In order to assess the said enterprise's CSR initiative, the impact it had on the quantities used of some strategic input such as water, electricity and gas, in the production process was examined. The following is deduced:

- Water: It is worth, at this stage, pointing out that the technology used by this plant to reduce different types of emission during the first period of the study (i.e., between 1978 and 2005) was a water dependent technology which demands considerable quantities of water at the expense of the neighbouring inhabitants.

- Gas: In order to limit the risks of breakdown of the furnace, the enterprise, decided in 2009, to adopt a new technology.

- Electricity: With the aim of reducing the amount of electricity consumed during the production process and in accordance with CSR requirements, the enterprise decided, in 2006, to adopt a new policy consisting of electrical load shedding during peak demand periods, where the cost of a $\mathrm{kWh}$, in Algeria, is on average, more than ten times the cost of the same unit in off-peak hours.

\section{Results and Findings}

In order to compare the evolution of the two indicators cited above, any inflationary impact was omitted by using the consumer price index (CPI) as a deflator. Consequently, Table 4 was obtained.

Table 4. The evolution of the production and the VA

\begin{tabular}{|c|c|c|c|c|}
\hline Year & $\operatorname{Prod}(\mathbf{T})$ & $\begin{array}{c}\text { VA } \\
\left(10^{3} \text { Euros }\right)\end{array}$ & CPI & $\begin{array}{c}\text { Real VA } \\
\left(\mathbf{1 0}^{3} \text { Euros }\right)\end{array}$ \\
\hline 2000 & 1031997 & 14858 & 100 & 14858,26 \\
\hline 2001 & 911269 & 14557 & 104,21 & 13969,21 \\
\hline 2002 & 913106 & 14500 & 105,73 & 13714,5 \\
\hline 2003 & 1003934 & 17980 & 108,48 & 16575,18 \\
\hline 2004 & 1000077 & 17890 & 112,32 & 15927,07 \\
\hline 2005 & 968130 & 20180 & 114,16 & 17677,49 \\
\hline Mean value & 971419 & 16661 & - & 15453.62 \\
\hline 2006 & 980429 & 20550 & 117,03 & 17559,01 \\
\hline 2007 & 1107651 & 27020 & 121,15 & 22302,69 \\
\hline
\end{tabular}




\begin{tabular}{|l|l|l|l|l|}
\hline 2008 & 1137685 & 25690 & 126,55 & 20299,52 \\
\hline 2009 & 1161000 & 28140 & 136,63 & 20595,68 \\
\hline 2010 & 1054748 & 42490 & 141,95 & 29932,92 \\
\hline 2011 & 1219096 & 45190 & 148,39 & 30453,45 \\
\hline 2012 & 1266004 & 47910 & 161,57 & 29653,54 \\
\hline 2013 & 1280414 & 53371 & 169 & 31579,29 \\
\hline 2014 & 1310148 & 58353 & 177,46 & 32883,3 \\
\hline Mean value & $\mathbf{1 1 6 8 5 7 5}$ & $\mathbf{3 8 7 4 6}$ & - & $\mathbf{2 6 1 3 9 . 9 3}$ \\
\hline Evolution & $\mathbf{2 0 , 3 0 \%}$ & - & - & $\mathbf{6 9 , 1 5 \%}$ \\
\hline
\end{tabular}

Source: The author, from the SCAEK accounting records.

From the above table, it can be seen that the mean value of both indicators had sensibly increased in the second period i.e. after implementing the EEA. The value had increased by more than $20 \%$ and $69 \%$ for the production volume and the VA respectively. The increase in the production was due to the recuperation of the cement dust which used to pollute the atmosphere. However, the use of new filters raised the level of workers' productivity as a consequence of improving the work conditions (Sahraoui \& Guerfi, 2016). Hence, it can be said that the EEA has had a positive impact on the enterprise's economic performance.

As far as the input were concerned, it was found that:

Concerning the plant - The plant used to consume, on average, more than 250000 m3/year during that period. After implementing the EEA, the quantity used was reduced by more than $50 \%$ to the delight of the local population who would now have access to more quantities of water.

Concerning the gas - As a result, of installing new equipment that is less polluting, the consumption of gas was reduced from 123.86 in 2006 to $104.67 \mathrm{~m} 3 / \mathrm{T}$ produced of clinker in 2015.

As a consequence of its new policy of reducing the quantity of electricity used, the load shedding time increased from 1347 hours to 3437 hours from the year 2005 to 2009, which has contributed to a significant reduction in the variable costs.

\section{Conclusion}

The analysis of this study suggests that even if the relation between CSR and economic performance was still debatable among academic works, there is still good to be achieved out of the CSR. In the case of the SCAEK Company, it is noted that managers who had embarked on a strategy for the sole purpose of reducing all kinds of pollution emitted actually did not stop when their objectives were achieved. In fact, they continued along their encouraging paths by setting up new measures which could reduce the quantities used of some input and improving the working conditions of the employees. The latter, stimulated by their new work environment, appreciated the care and attention they received and they became more conscious of the dangers of competition coming from other cement companies. Consequently, they spared no effort in raising their productivity. All this had resulted in a sensible increase in the quantity produced and the wealth created by the enterprise. As a concluding remark, it is asserted that the right implementation of the CSR, even if it requires some additional costs, can result in a "win-win" situation. However, the current study needs to be followed-up by other studies so as to investigate this relationship in more detail.

\section{References}

Bénabou, R., \& Tirole, J. (2010). Individual and corporate social responsibility. Economica, 77(305), 1-19.

CSR Europe. (2010). CSR Europe on outlines new strategy, leadership and action plan, Conference held in Belgium, June 2010. Retrieved from http://www.csreurope.org/csr-europe-outlines-new-strategy-leadership-and-actionplan on 07/07/2016.

Fifka, M. S. (2009). Towards a more business-oriented definition of corporate social responsibility: Discussing the core controversies of a well-established concept. Journal of Service Science and Management, 2(04), 312. 
Harrison, J. S., \& Freeman, R. E. (1999). Stakeholders, social responsibility, and performance: Empirical evidence and theoretical perspectives. Academy of management Journal, 42(5), 479-485.

Sahraoui, H.H. \& Guerfi, C. (2016). The Role of Human factors engineering in Enhancing Corporate Social Responsibility Towards Employees: The Case of the Cement Company of Ain El Kebira, Revue Cahiers Economiques, 13.

Lerner, L. D., \& Fryxell, G. E. (1988). An empirical study of the predictors of corporate social performance: A multidimensional analysis. Journal of Business Ethics, 951-959.

Margolis, J. D., \& Walsh, J. P. (2003). Misery loves companies: Rethinking social initiatives by business. Administrative science quarterly, 48(2), 268-305.

Porter, M. E., \& Van der Linde, C. (1995). Green and competitive: ending the stalemate. Harvard business review, 73(5), 120-134.

Raza, A., Ilyas, M. I., Rauf, R., \& Qamar, R. (2012). Relationship between corporate social responsibility (CSR) and corporate financial performance (CFP): Literature review approach. Elixir Financ. Manag, 46, 8404-8409.

Islam, Z. M., Ahmed, S. U., \& Hasan, I. (2012). Corporate social responsibility and financial performance linkage: Evidence from the banking sector of Bangladesh.

SCAEK environmental approach report (2012).

Stefan, A., \& Paul, L. (2008). Does it pay to be green? A systematic overview. The Academy of Management Perspectives, 22(4), 45-62.

Srivastava, A. K., Negi, G., Mishra, V., \& Pandey, S. (2012). Corporate social responsibility: a case study of Tata Group. IOSR Journal of Business and Management, 3(5), 17-27.

Uadiale, O. M., \& Fagbemi, T. O. (2012). Corporate social responsibility and financial performance in developing economies: the Nigerian experience. Journal of Economics and Sustainable Development, 3(4), 44-54. 